\title{
Potential applications of cyanobacteria: Spirulina platensis filtrates and homogenates in agriculture
}

\author{
K. Godlewska' ${ }^{1}$ I. Michalak ${ }^{2}$ - P. Pacyga ${ }^{3} \cdot$ S. Baśladyńska² $\cdot$ K. Chojnacka ${ }^{2}$
}

Received: 23 December 2018 / Accepted: 10 May 2019 / Published online: 27 May 2019

(c) The Author(s) 2019

\begin{abstract}
In the present paper, products obtained from a blue-green microalga Spirulina platensis filtrate (applied for seed soaking and for foliar spray) and homogenate (used for seed coating) were tested in the cultivation of radish. Their effect on length, wet mass, multielemental composition and the greenness index of the radish leaves was examined. Multi-elemental analyses of the algal products, and radish were also performed using inductively coupled plasma-optical emission spectrometry (ICPOES). The best soaking time, concentrations of filtrate and doses of homogenate were established. The longest and heaviest plants were observed for homogenate applied at a dose of $300 \mu \mathrm{L}$ per $1.5 \mathrm{~g}$ of seeds and $15 \%$ of filtrate applied as foliar spray. The highest chlorophyll content was found in the group treated with $100 \mu \mathrm{L}$ of homogenate and $5 \%$ of filtrate. In the case of soaking time, the longest plants were in the group where seeds were soaked for $6 \mathrm{~h}$, but the heaviest and greenest were after soaking for $48 \mathrm{~h}$. The applied algal products increased the content of elements in seedlings. Obtained results proved that algal extracts have high potential to be applied in modern horticulture and agriculture. The use of Spirulina-based products is consistent with the idea of sustainable agriculture that could help to ensure production of sufficient human food to meet the needs of rising population and protection of the environment.
\end{abstract}

Keywords Filtrate $\cdot$ Foliar spray $\cdot$ Homogenate $\cdot$ Biostimulant $\cdot$ Seed coating $\cdot$ Seed soaking $\cdot$ Spirulina platensis

\section{Introduction}

Recently, intense research on microalgal formulations useful in cultivation of plants is observed. Algae are characterised by higher productivities than terrestrial plants and can be used for the production of valuable products for plants, including fertilizers (Wuang et al. 2016). Cyanobacteria can play a crucial role in the sustainable agriculture that

I. Michalak

izabela.michalak@pwr.edu.pl

1 Department of Horticulture, The Faculty of Life Sciences and Technology, Wrocław University of Environmental and Life Sciences, pl. Grunwaldzki 24A, 50-363 Wrocław, Poland

2 Department of Advanced Material Technologies, Faculty of Chemistry, Wrocław University of Science and Technology, Smoluchowskiego 25, 50-372 Wrocław, Poland

3 Department of Design Fundamentals and Fluid-Flow Machinery, Faculty of Mechanical and Power Engineering, Wrocław University of Science and Technology, Na Grobli 15, 50-421 Wrocław, Poland contributes to the soil fertility, crop growth and yield and improvement of the environmental quality (Singh et al. 2016; Osman et al. 2016). The use of dried cyanobacteria to inoculate soil in order to increase its fertility is called "algalization". Mishra and Pabbi (2004) showed that the addition of algae to the soil can increase rice yield by $15-20 \%$ in field experiments. Cyanobacterial biomass is also known to improve soil physicochemical characteristics such as water-holding capacity and mineral status of the degraded soils (Singh et al. 2016). Many cyanobacteria [e.g., Nostoc muscorum, Nostoc humifusum, Anabaena oryzae and Wollea sp. (Hegazi et al. 2010)] are capable of using atmospheric nitrogen as a source of nitrogen (nitrogen fixation) (Bhowmik et al. 2010; Mishra and Pabbi 2004; Singh et al. 2016) which may reduce the amount of synthetic nitrogen fertilizers used in agriculture (Bhowmik et al. 2010; Hegazi et al. 2010). In the work of Hegazi et al. (2010) it was suggested that $1 / 4$ or $1 / 2$ of the recommended dose of nitrogen mineral fertilizer could be reduced by using some species of cyanobacteria capable of nitrogen fixation. Spirulina formulations can be treated as biostimulants of plant growth, which according to the definition presented by du Jardin 
(2015) are "any substances or microorganisms applied to plants with the aim to enhance nutrition efficiency, abiotic stress tolerance and/or crop quality traits, regardless of its nutrients content".

Arthrospira platensis (Spirulina platensis) can be used as a rich source of macro- and micronutrients for plants-for example vitamins, amino acids, polypeptides, phytohormones (gibberellins, auxins, cytokinins), antioxidants and compounds with antibacterial and antifungal properties (Bhowmik et al. 2010; Osman et al. 2016; Nawrocka et al. 2017). Despite their unique chemical composition, microalgae are not as often used for agricultural purposes as macroalgae (seaweeds). This can result from the availability of seaweed biomass - it is usually abundant in many marine and freshwater reservoirs, whereas microalgae are usually cultivated in the artificial conditions. Therefore, they constitute more expensive source of biomass for the production of biostimulants of plant growth.

Literature review on the application of Spirulina in plant cultivation is presented in Table 1. In most cases, Spirulina was applied directly to the soil or was added in the form of the algal suspension. Plants biofortified with the macro- and micronutrients of cyanobacterial origin can be used as novel, functional food preventing the malnutrition (Tuhy et al. 2015; Mala et al. 2017). Mala et al. (2017) used S. platensis as a fertilizer for agronomic biofortification of Amaranthus dubius (the red spinach) with carbohydrates, proteins, essential macronutrients, micronutrients and vitamin A. Post-extraction residues after supercritical $\mathrm{CO}_{2}$ extraction of $S$. platensis enriched with $\mathrm{Zn}$ (II), $\mathrm{Cu}$ (II) $\mathrm{Mn}$ (II) ions using biosorption were used as NPK fertilizer bio-components to biofortify maize in field trials with these micronutrients (Tuhy et al. 2015). Anitha et al. (2016) used S. platensis as a biofortified material to enhance zinc level in cultivars of a vegetable amaranth (Amaranthus gangeticus), mung bean (Phaseolus aureus) and tomato. Enzymatic hydrolysates of S. Platensis contain polyamines (e.g., spermine) obtained by the decarboxylation of algal L-amino acids, which are known to promote plant growth (Mógor et al. 2018). Different approach was proposed by Osman et al. (2016) who used $S$. platensis as a natural safener (instead of chemical) against harmful effects of fusilade herbicide on faba bean plant (faba bean seeds were primed in a S. platensis suspension before cultivation).

In this study, the blue-green microalga, $S$. platensis was used as a raw material for the production of filtrate (applied for seed soaking and for foliar spray) and homogenate (used for seed coating). Natural products were tested in the cultivation of radish (Raphanus sativus) in the germination tests. Seed industry is nowadays recognized as a crucial sector that can increase the productivity of crops (Singh et al. 2015). Therefore, the aim of the research was to examine the effect of the obtained bioproducts on the morphological indicators of radish seedlings (length of above-ground biomass, weight of wet biomass, chlorophyll content in the biomass), as well as on the biofortification of the above-ground radish biomass with micro- and macroelements derived from microalga.

\section{Materials and methods}

\section{Chemicals and microalgae biomass}

The $69 \%$ nitric acid, spectrally pure (Suprapur) was purchased from Merck KGaA (Darmstadt, Germany) and dried biomass of Spirulina platensis from WB Im-und Export W. Beringer \& Co. GmbH (Görmin/Böken; Germany) in 2016.

\section{Production of preparations}

Homogenate was prepared by a suspension of dry S. platensis in deionised water (in a ratio 1:10) and mixing (Thermomix; Vorkwerk Ltd., Poland) at $37^{\circ} \mathrm{C}$ for $40 \mathrm{~min}$. (500 rpm). The obtained solution was centrifuged for 20 min. (4600 rpm) (Heraeus Megafuge 40, rotor TX-750, Thermo Scientific, Waltham, MA, USA). Supernatant was separated and treated as an algal filtrate (F) $-100 \%$ and then (1) foliarly applied to the sprouts as an aqueous solution at different concentrations $(5,7,10,15,20$ and $25 \%, v / v)$. The $15 \%$ concentration was used for (2) seeds soaking for different time spans- $1,3,6,12,18,24,36$ and $48 \mathrm{~h}$. The remaining solid residue, treated as an algal homogenate $(\mathrm{H})-100 \%$, was diluted with deionised water (1:1) and used for (3) seeds coating (doses-100, 300, 500, $700 \mu \mathrm{L}$ per $1.5 \mathrm{~g}$ of radish seeds). This treatment was performed using vortex-type shaker for $10 \mathrm{~min}$. The concentrations were selected on the basis of our previous studies (Michalak et al. 2017).

\section{Germination tests-Petri dish tests}

The phytotoxicity of the algal formulations was evaluated in the germination tests. Experiments were carried out under controlled conditions: $21 \pm 1{ }^{\circ} \mathrm{C}$, constant humidity and 12/12 h light/dark photoperiod, limiting the risk of abiotic and/or biotic stress. As a model plant, radish (Raphanus sativus 'Caro', TORSEED, Toruń, Poland) was chosen. Radish seeds-without pre-treatment, as well as soaked in the Spirulina filtrate and treated with Spirulina homogenate are presented in Fig. 1. Experiments were conducted on Petri dishes, in 3 replications for each group in standardized conditions using Jacobsen apparatus (Laborset, Łódź, Poland) according to the international norm (International Rules for Seed Testing, 2011-International Seed Testing Association (Bassersdorf, Switzerland)). On each Petri dish (diameter $85 \mathrm{~mm}$ ), 25 seeds were placed on moistened cotton wool 


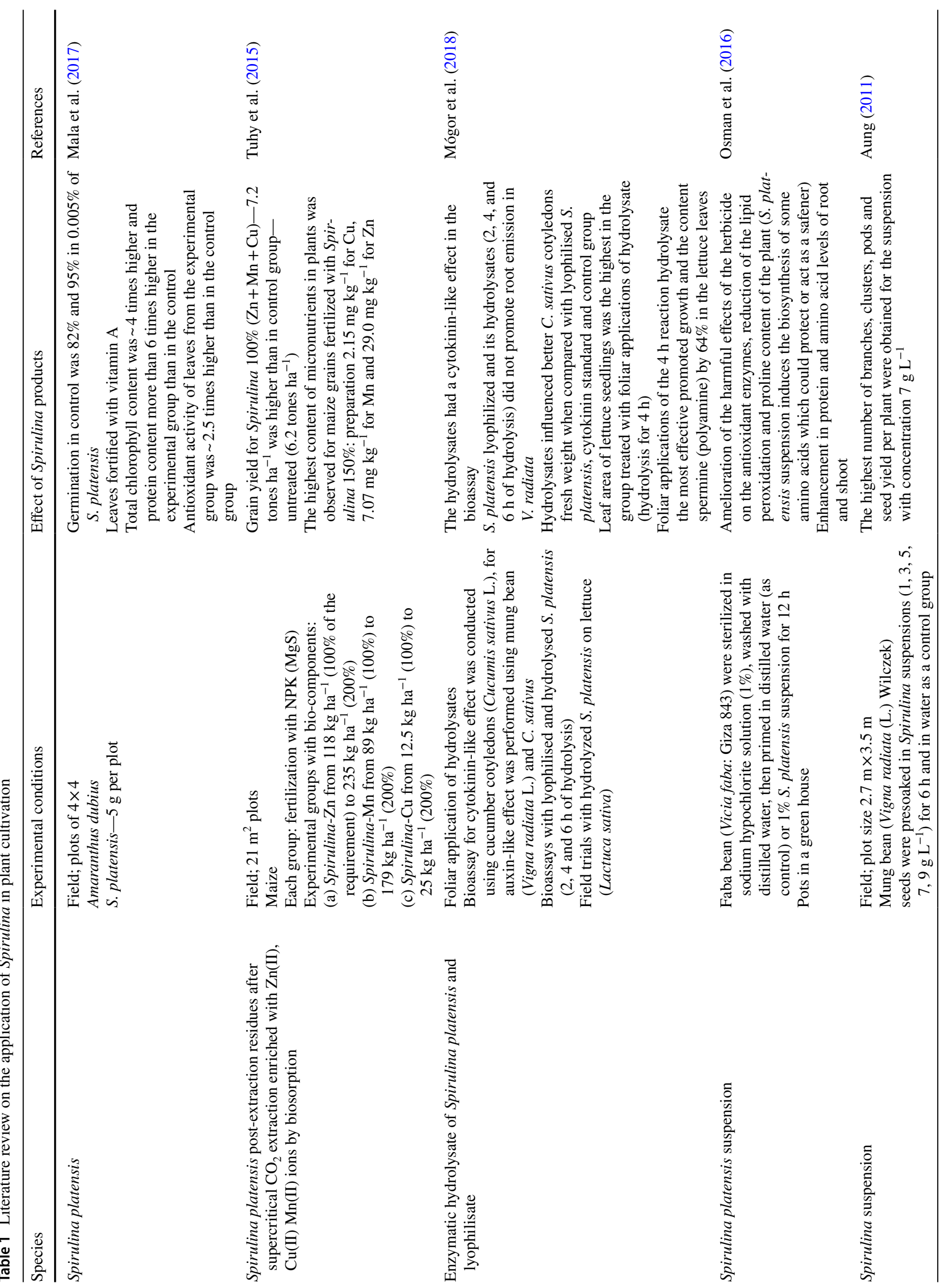




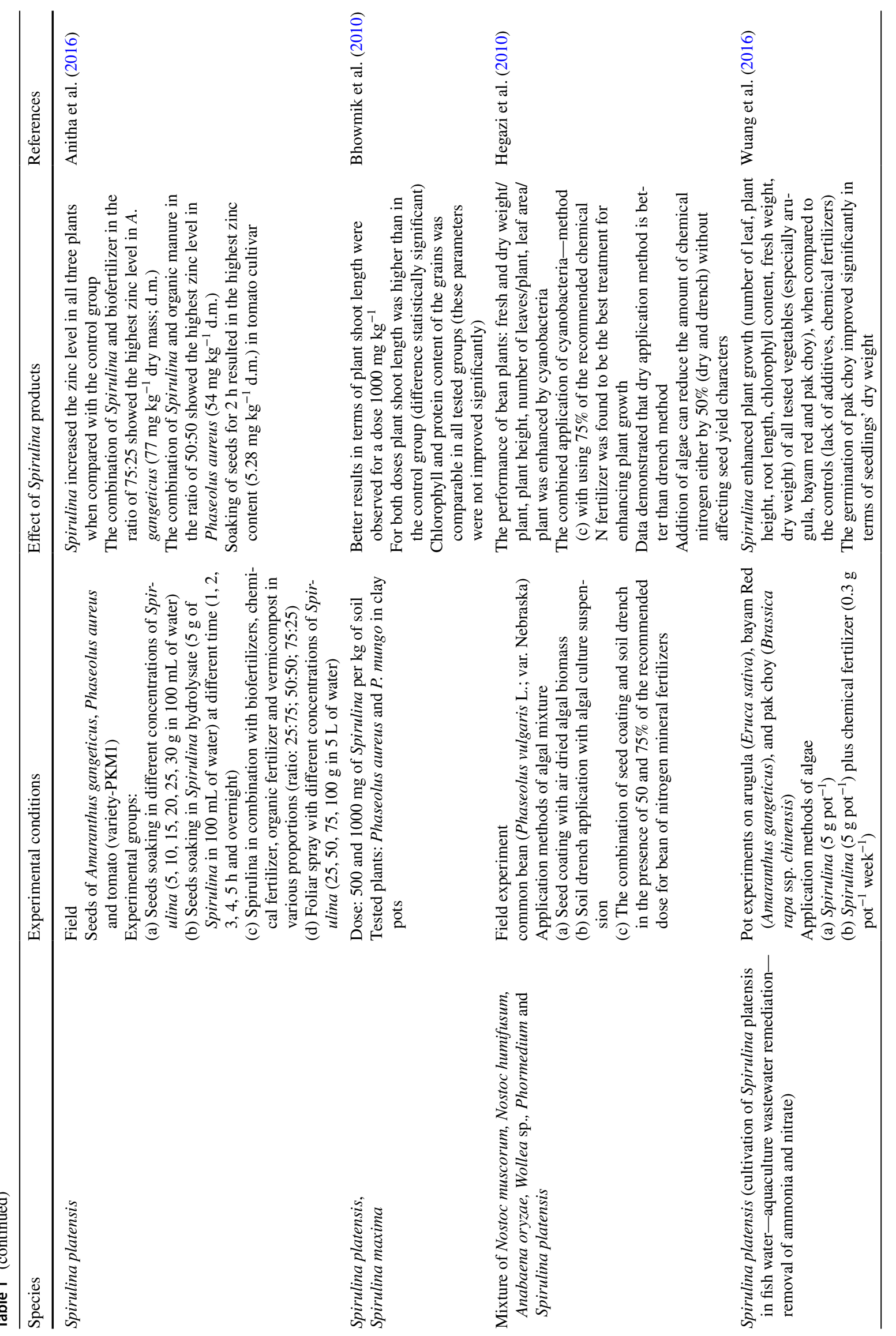




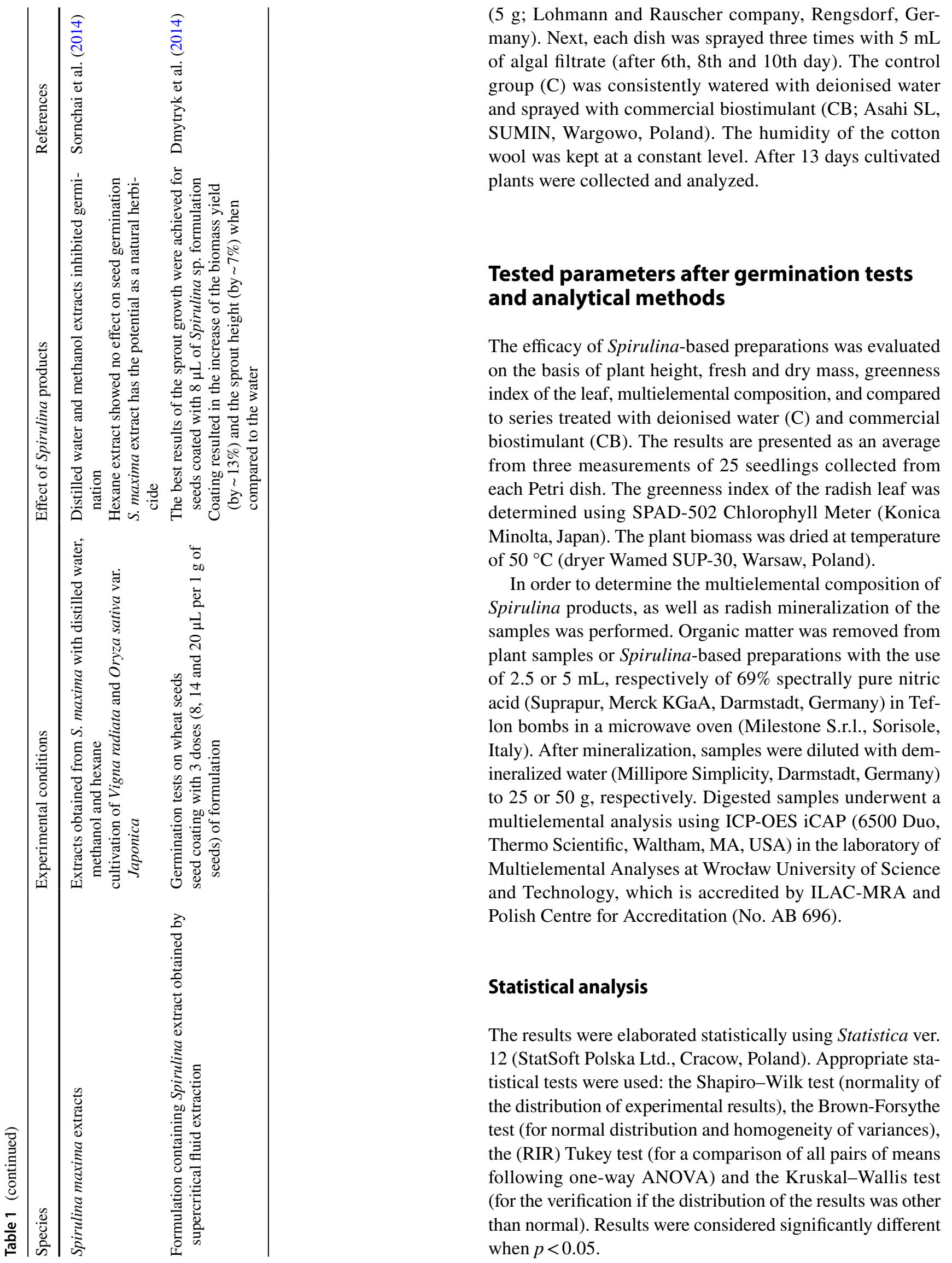


(a)

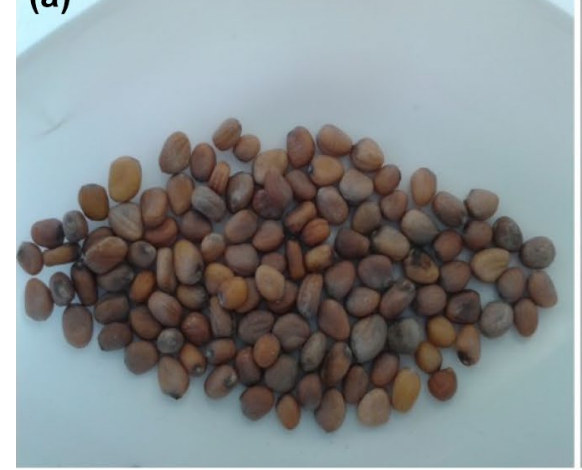

(b)

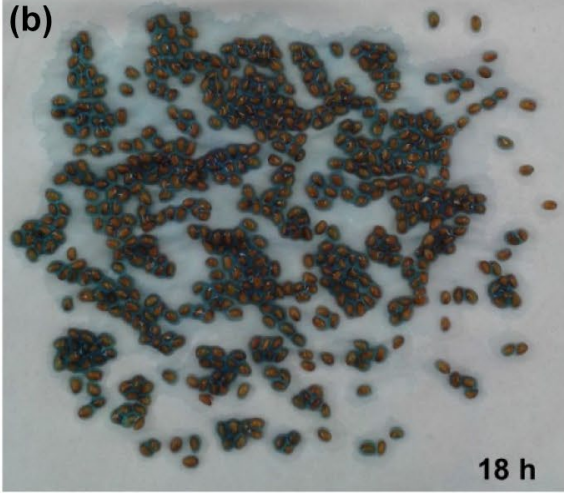

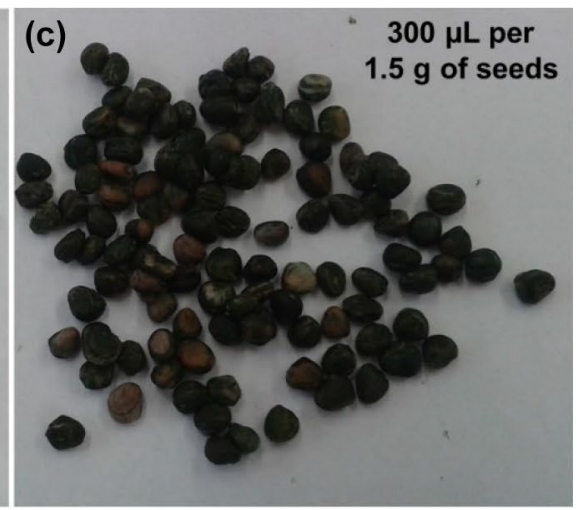

Fig. 1 Radish seeds without pre-treatment (a), radish seeds soaked (b) and treated with Spirulina homogenate (c)

\section{Results}

\section{Multielemental composition of Spirulina platensis products}

In the present study, S. platensis was homogenized and then centrifuged. The liquid part-supernatant was used as a filtrate/extract for plants spraying (as a biostimulant of plant growth) and for seeds soaking before sowing, whereas the solid residue was used for seeds coating also before their sowing. Table 2 presents a multielemental composition of S. platensis products-filtrate and homogenate and commercial biostimulant of plant growth. It is worth noting that macroelements- $\mathrm{K}, \mathrm{Mg}, \mathrm{P}, \mathrm{S}$ occurred in larger quantities in a homogenate than in filtrate, whereas microelements - $\mathrm{Cu}$, $\mathrm{Fe}, \mathrm{Ni}$ and $\mathrm{Zn}$ in an algal filtrate. The content of all studied elements was much higher in Spirulina products than in the commercial biostimulant. Therefore, microalga products not only improve plant growth and development but also enhance the mineral composition of cultivated plants.

\section{The effect of Spirulina products on morphological indicators of radish seedlings}

The effect of homogenate (doses-100, 300, 500, $700 \mu \mathrm{L}$ per $1.5 \mathrm{~g}$ of radish seeds) used for seeds coating, $15 \%$ filtrate used for seeds soaking (time span-1, 3, 6, 12, 18, 24, 36, $48 \mathrm{~h}$ ) and filtrate used for foliar spray (concentrations- 5 , $7,10,15,20$ and $25 \%$ ) on the length of the above-ground biomass, wet and dry mass was examined. The example of
Table 2 Multielemental composition of Spirulina platensis products-filtrate, homogenate and commercial product $\left(\mathrm{mg} \mathrm{L}^{-1}\right)$

\begin{tabular}{lllll}
\hline Element/wavelength $(\mathrm{nm})$ & S. platensis filtrate & S. platensis homogenate & $\begin{array}{l}\text { Commercial } \\
\text { biostimulant } \\
(\mathrm{CB})\end{array}$ \\
\hline $\mathrm{Al}$ & 308.215 & $197.2 \pm 29.6$ & $756.1 \pm 113.4$ & $<1.0$ \\
$\mathrm{Ca}$ & 315.887 & $3042 \pm 608$ & $3141 \pm 628$ & $40.76 \pm 31.38$ \\
$\mathrm{Cr}$ & 267.716 & $<0.3$ & $3.236 \pm 0.485$ & $<0.3$ \\
$\mathrm{Cu}$ & 324.754 & $3.364 \pm 0.505$ & $3.947 \pm 0.592$ & $0.3407 \pm 0.1979$ \\
$\mathrm{Fe}$ & 259.940 & $353.6 \pm 53.0$ & $1464 \pm 293$ & $<0.4$ \\
$\mathrm{~K}$ & 766.491 & $38,687 \pm 7737$ & $9641 \pm 1928$ & $3.037 \pm 0.356$ \\
$\mathrm{Mg}$ & 285.213 & $4588 \pm 918$ & $2701 \pm 540$ & $5.120 \pm 2.689$ \\
$\mathrm{Mn}$ & 257.61 & $74.40 \pm 11.16$ & $46.64 \pm 7.00$ & $<0.25$ \\
$\mathrm{Na}$ & 588.995 & $13,375 \pm 2675$ & $3753 \pm 751$ & $<328 \pm 18$ \\
$\mathrm{Ni}$ & 231.604 & $2.289 \pm 0.343$ & $8.096 \pm 1.214$ & $<10$ \\
$\mathrm{P}$ & 213.618 & $18,687 \pm 3737$ & $7336 \pm 1467$ & $<10$ \\
$\mathrm{~S}$ & 181.972 & $7234 \pm 1447$ & $6789 \pm 1358$ & $2.545 \pm 0.879$ \\
$\mathrm{Si}$ & 251.611 & $154.0 \pm 23.1$ & $119.1 \pm 17.9$ & $1.499 \pm 0.790$ \\
$\mathrm{Zn}$ & 213.857 & $18.74 \pm 2.81$ & $19.42 \pm 2.91$ & \\
\hline
\end{tabular}


the radish germination tests with Spirulina filtrates is presented in Fig. 2.

\section{The effect of Spirulina products on the above-ground radish length.}

After 13 days of the experiment, plants from each replication $(\mathrm{N}=3)$ were collected and the length was determined for all Spirulina-based products and control groups. Both algal and commercial biostimulant showed a beneficial effect on the length of model plant. In order to verify the statistically significant differences between the tested groups, analyses were performed using STATISTICA software.

The effect of a foliar spray of Spirulina filtrate on the radish length is presented in Fig. 3a. It was observed that with the increasing concentration of the preparation, the length of plants increased. However, a decreasing biostimulating activity was observed above $15 \%$ concentration of the filtrate. The application of $15 \%$ solution influenced radish length in the highest extent, which was 129 and $71 \%$ longer than in $\mathrm{C}$ and $\mathrm{CB}$, respectively. The statistically significant differences (for $p<0.05$ ) were observed between the control group $(\mathrm{C})$ and all the tested concentrations of biostimulants, but not for CB. Statistically significant differences were observed between $\mathrm{CB}$ and extracts at concentrations of 7 , 10,15 and $20 \%$.

The effect of seeds soaking in 15\% Spirulina filtrate on the above-ground biomass length is presented in Fig. $3 b$. Soaking time in $15 \%$ algal filtrate showed varying degree of a stimulating effect on the radish growth. All Spirulina treatments had a beneficial influence on the radish growth in comparison with the control group (C). The best time for seeds soaking proved to be $6 \mathrm{~h}$ where plants were higher when compared with $\mathrm{C}$ by $44.5 \%$ and CB by $7.7 \%$. A longer time of seeds treatment in filtrate showed to be ineffective. The statistically significant differences were found between the control group and soaking for 6, 24 and $36 \mathrm{~h}$ and CB, and between CB and seeds soaking for $18 \mathrm{~h}$.

The effect of seeds coating in Spirulina homogenate on the above-ground radish length is presented in Fig. 3c. All Spirulina-based homogenates showed greater biostimulating properties than the commercial product. The highest plants were obtained in a group treated with $300 \mu \mathrm{L}$ of homogenate per $1.5 \mathrm{~g}$ of seeds. In this group, plants were higher respectively by 60.5 and $20 \%$ in comparison with C and CB. The statistically significant differences were observed between the control group and all the tested homogenate's doses and the commercial biostimulant. In comparison with $\mathrm{CB}$, the difference was noted only for $300 \mu \mathrm{L}$.

\section{The effect of Spirulina products on the fresh mass of radish}

First, the effect of a foliar spray of Spirulina filtrate on the fresh mass of radish was tested. As can be seen from Fig. 4a, for the $15 \%$ concentration of microalgal filtrate-plants were heavier by 151 and $72 \%$ than in the control and commercial biostimulant group, respectively. With the increasing concentration of filtrates, the fresh mass was decreasing. The statistically significant differences were reported between the groups treated with 10 and $15 \%$ filtrate and the control group.

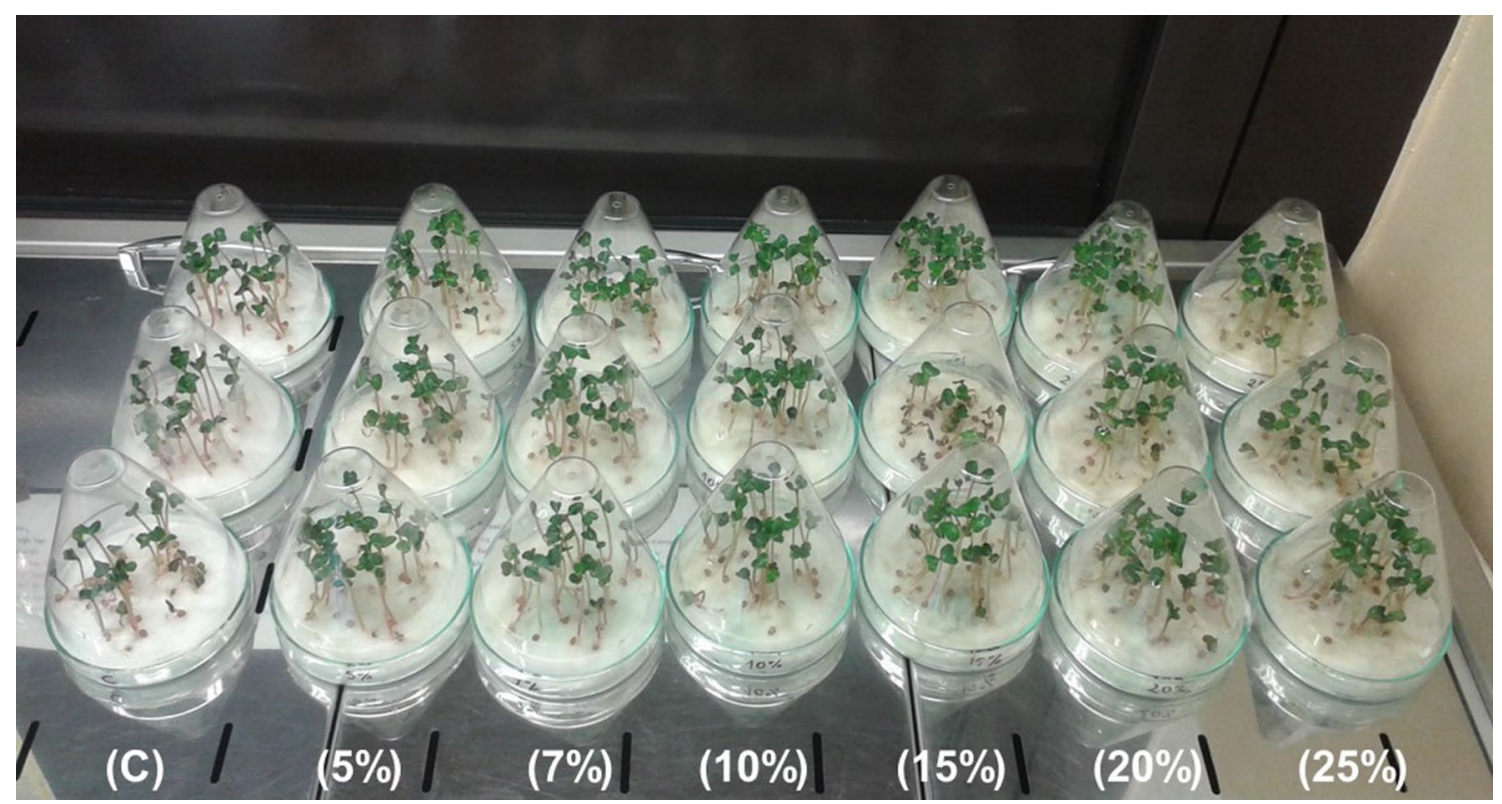

Fig. 2 Germination tests of radish treated with Spirulina filtrate 
Fig. 3 The effect of a a foliar spray of Spirulina filtrate, b seeds soaking in Spirulina filtrate (1-48 h), c seeds coating in Spirulina homogenate (100-700 $\mu \mathrm{L}$ per $1.5 \mathrm{~g}$ of seeds) on the radish length $(\mathrm{cm} ; \mathrm{N}=3)$
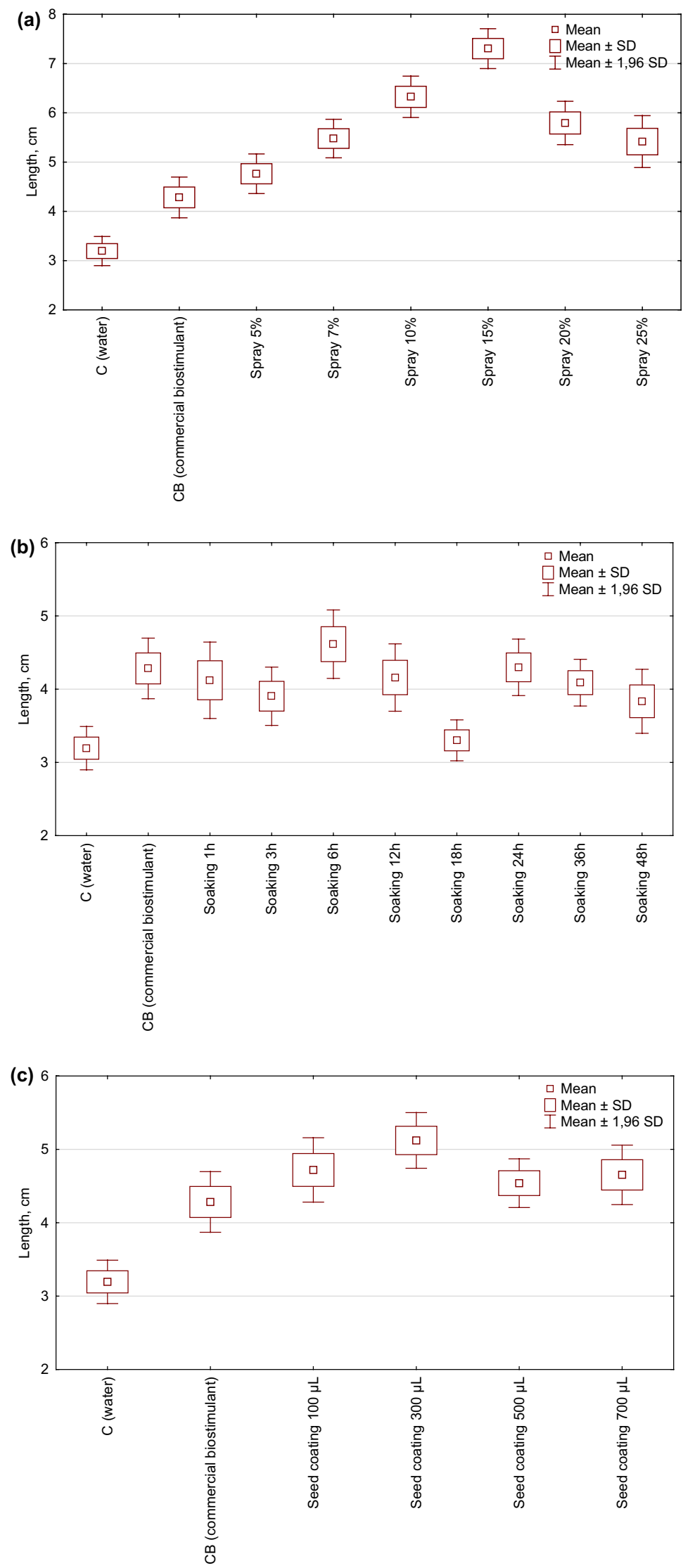
Fig. 4 The effect of a a foliar spray of Spirulina filtrate, $\mathbf{b}$ seeds soaking in Spirulina filtrate (1-48 h), c seeds coating in Spirulina homogenate (100-700 $\mu \mathrm{L}$ per $1.5 \mathrm{~g}$ of seeds) on the radish wet mass ( $\mathrm{g}$; $\mathrm{N}=3$ )
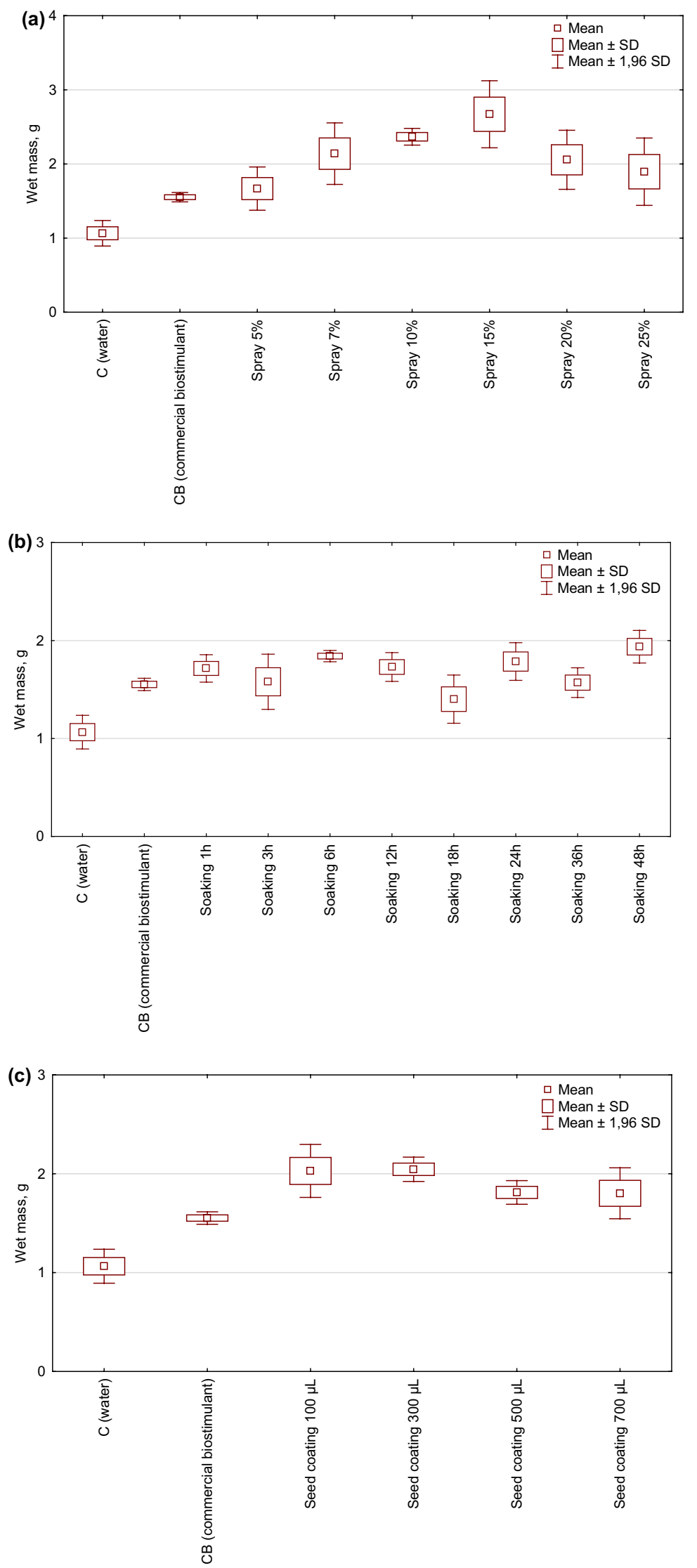
The effect of seeds soaking in 15\% Spirulina filtrate on the radish fresh mass is presented in Fig. 4b. Soaking of seeds showed stimulating effect on the plants fresh biomass. Generally, in all experimental groups, the plant mass was higher when compared with $\mathrm{C}$ and $\mathrm{CB}$. The best result was observed for the longest time ( $48 \mathrm{~h}$ ) of seeds soaking (increase by 81 and $25 \%$ when compared with C and CB, respectively). The lightest plants were in a group where seeds were soaked for $18 \mathrm{~h}$ (heavier by $31 \%$ than in $\mathrm{C}$ and lighter by $9.7 \%$ than in CB). The statistically significant differences were found between the control and experimental group (except $18 \mathrm{~h}$ ) and commercial biostimulants. In comparison with CB, produced Spirulina extracts did not show any significant differences.

Finally, we tested the effect of seeds coating in Spirulina homogenate on the radish fresh mass. The results showed that the applied biostimulants positively influenced the fresh mass of radish (Fig. 4c). It could be noticed that the highest masses were in the groups treated with 300 and $100 \mu \mathrm{L}$ of homogenate (92 and 90\% heavier than in C; 32.3 and 31\% heavier than in $\mathrm{CB}$ ). The increasing dose of preparations (500 and $700 \mu \mathrm{L}$ ) emerged to be less effective (69 and 68\% heavier than in $\mathrm{C}$ and 17 and $16 \%$ than in CB). The statistically significant differences were observed only between the control group and $300 \mu \mathrm{L}$ of homogenate.

\section{The effect of Spirulina products on the greenness index of the radish leaf}

The foliar application of Spirulina filtrate on radish seeds resulted in the increased content of green pigment (Fig. 5a). In the groups $15 \%<7 \%<10 \%<25 \%$ the greenness index was statistically insignificant in comparison with the control group. The application of 5\% filtrate statistically enhanced the greenness by 17 and $7.2 \%$ when compared to the control and the commercial product, respectively. Another statistically significant difference was observed in the group treated with $20 \%$ filtrate (6.8\% higher when compared to C). No statistically significant differences were observed between the commercial product and the control group and tested filtrates.

The seeds soaking in a Spirulina filtrate increased the greenness index of the radish leaf in all the tested groups (Fig. 5b). The greenest leaves were noticed for $48 \mathrm{~h}$ of seeds soaking (32 and $20 \%$ more than in $\mathrm{C}$ and $\mathrm{CB}$, respectively). The least biostimulating properties showed time of $12 \mathrm{~h}$ where the SPAD value was higher by about 15 and $4.8 \%$ in comparison with $\mathrm{C}$ and $\mathrm{CB}$. The statistically significant differences were observed for all tested biostimulants (except $12 \mathrm{~h}$ and commercial product) when compared with the control. The soaking time- 1,18 and $48 \mathrm{~h}$ showed significant differences in comparison with CB.
The application of homogenates for seed coating resulted in the increased greenness index of the radish leaves (Fig. 5c). The highest chlorophyll content was noticed in a group treated with $100 \mu \mathrm{L}$ of preparation (19 and $9.2 \%$ more than in $\mathrm{C}$ and $\mathrm{CB}$, respectively) while the lowest with $500 \mu \mathrm{L}$ (15\% more than in C). The statistically significant differences were noted between water (C) and 100, 300, $700 \mu \mathrm{L}$ of homogenates (not for CB). Among the tested Spirulina products, the highest greenness index of the radish leaves was recorded for the group with homogenate $(100 \mu \mathrm{L} / 1.5 \mathrm{~g}$ of seeds).

\section{Multielemental composition of the above-ground biomass of radish}

The effect of the different methods of the application of Spirulina products on the multielemental composition of radish was examined. Spirulina filtrate used as a foliar spray increased the content of plant micronutrients when compared with the control group (water)-Table 3. Boron and copper content generally increased with the increasing concentration of the algal filtrate (from 5 to $20 \%$ ). Decrease was observed after the application of $25 \%$ Spirulina filtrate. The content of B in radish was 2.5 times higher in the group with $20 \%$ filtrate than in the control group, for $\mathrm{Cu}$ it was $30 \%$. Iron content increased in the radish biomass with increasing concentration of Spirulina filtrate till the concentration of $20 \%$ (increase by $46 \%$ in relation to the control group). For $25 \%$ filtrate iron content decreased in the biomass, however it was higher than in the control group. Manganese content in all experimental groups was higher than in the control group, but the best results were obtained for $20 \%$ filtrate (increase by $34 \%$ ). The application of $20 \%$ filtrate resulted also in the highest nickel and zinc content in radish-increase by $\sim 5.5$ times and 55\% when compared with the water.

Concluding results on the multielemental composition of radish after the application of Spirulina filtrates it can be noted that the best effect was obtained for $20 \%$ filtrate. Higher filtrates concentrations, generally caused a decrease of microelements content in the radish biomass. Analogous results were obtained for macroelements content in the biomass of radish- $\mathrm{Ca}, \mathrm{K}, \mathrm{Mg}, \mathrm{P}$ and $\mathrm{S}$. Filtrate with the concentration of $20 \%$ most beneficially influenced their content in the biomass. Algal filtrates/extracts are known to be active at low concentrations (diluted as 1:1000 or more) (Crouch and van Staden 1993). It is worth noting that the content of micro- and macroelements in radish after application of $20 \%$ filtrate was higher than in the group with the commercial biostimulant. For microelements it was as follows: for $\mathrm{Ni}$ two times higher, $\mathrm{Zn}$ by $26 \%$, Fe by $24 \%$, B about $8 \%$ higher and slightly $\mathrm{Cu}$ by $2.5 \%$ and $\mathrm{Mn}$ by $1 \%$. Much larger differences were observed for the content of macroelements- $\mathrm{Ca}$ 
Fig. 5 The effect of a a foliar spray of Spirulina filtrate, $\mathbf{b}$ seeds soaking in Spirulina filtrate (1-48 h), c seeds coating in Spirulina homogenate (100-700 $\mu \mathrm{L}$ per $1.5 \mathrm{~g}$ of seeds) on the greenness index of the radish leaf $(\mathrm{N}=3)$
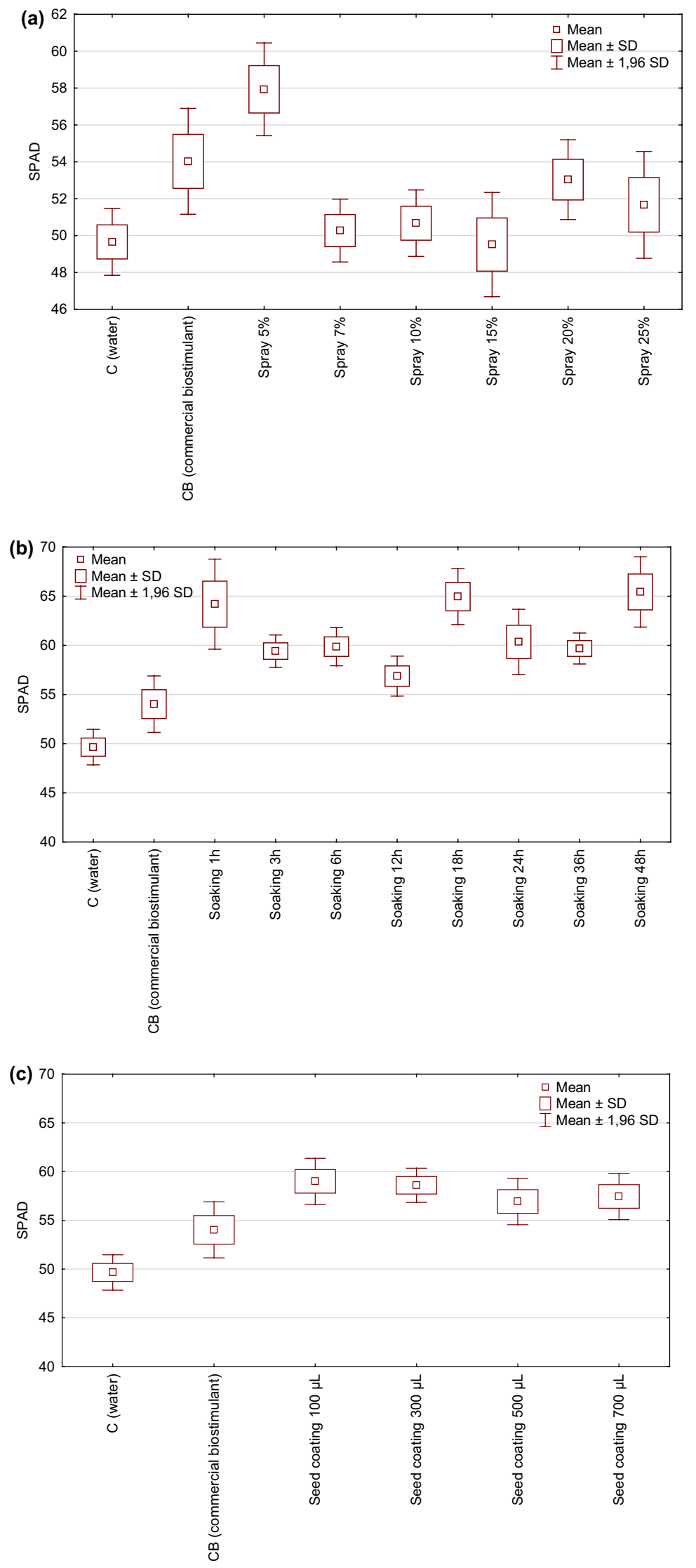


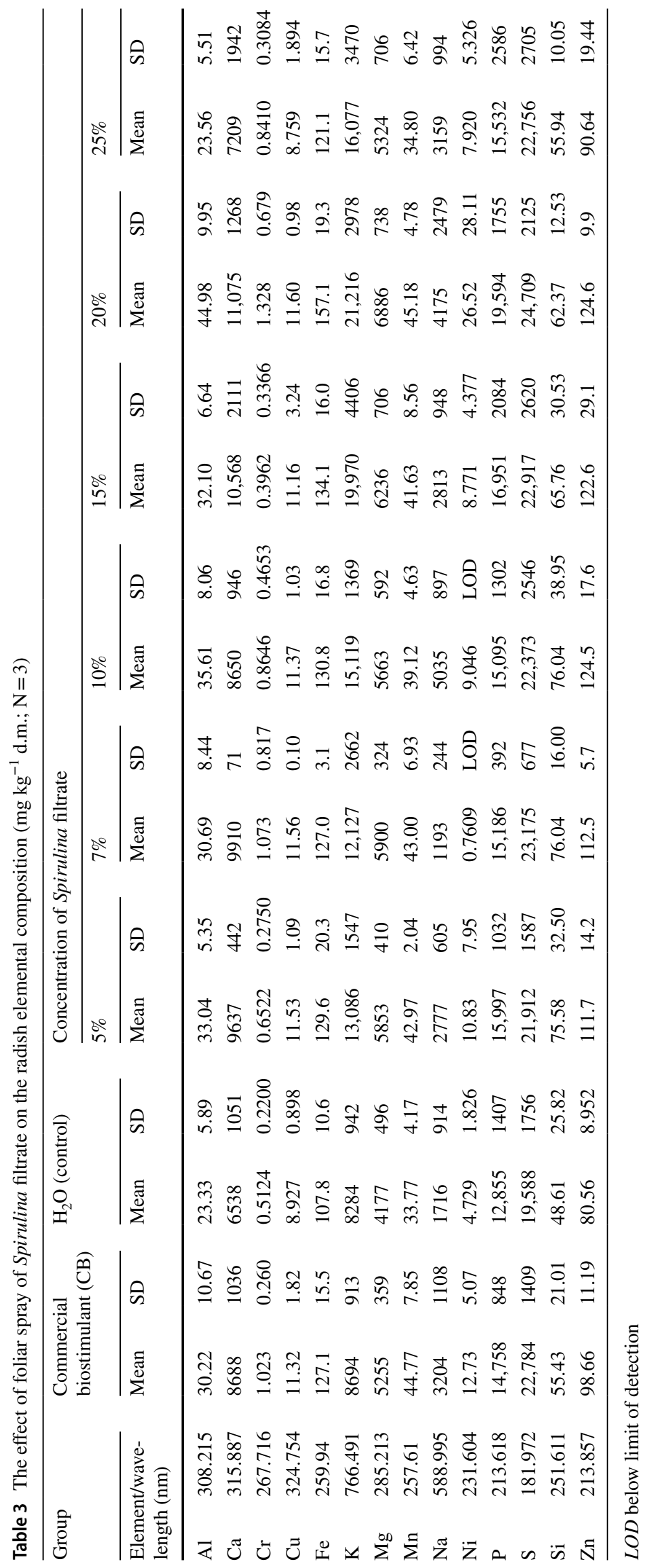


was by $27 \%$ higher in the group with $20 \%$ filtrate than for $\mathrm{CB}, \mathrm{K}$ was 2.5 times higher, $\mathrm{Mg}$ by $31 \%$, $\mathrm{P}$ by $33 \%$ and $\mathrm{S}$ by $8.5 \%$.

In the present study we also examined the effect of seed soaking in $15 \%$ Spirulina filtrate on the multielemental composition of radish. The content of elements in the cultivated radish is presented in Table 4 . It can be noted that soaking of seeds in Spirulina filtrate for more than $24 \mathrm{~h}$ generally negatively influenced the content of micro- and macroelements in the biomass. The best results were obtained for seed soaking for $24 \mathrm{~h}$. In the case of microelements, the visible differences between the experimental groups and the control group (water), as well as the group with commercial biostimulant were as follows: content of B was about 2.4 times higher $(1 \mathrm{~h})$ than in the control and by $6 \%$ than in $\mathrm{CB}$; content of $\mathrm{Cu}$ was by $36 \%$ higher $(24 \mathrm{~h})$ than in the control and by $7 \%$ than in $\mathrm{CB}$; content of Fe was by $17.5 \%$ higher (24 h) than in the control but slightly lower than in CB; content of Mn was by $31 \%$ higher ( $24 \mathrm{~h}$ ) than in the control and slightly lower than in $\mathrm{CB}$; content of $\mathrm{Ni}$ was about 2 times higher $(1 \mathrm{~h})$ than in the control but lower than in $\mathrm{CB}$ and content of $\mathrm{Zn}$ was by $38 \%$ higher $(24 \mathrm{~h})$ than in the control and by $12 \%$ than in $\mathrm{CB}$.

In the case of macroelements, it was noted that (for the best experimental groups) the content of $\mathrm{Ca}$ was by $21 \%$ higher $(24 \mathrm{~h})$ than in the control but lower than in CB; content of $\mathrm{K}$ was by $3.6 \%$ higher $(6 \mathrm{~h})$ than in the control but lower than in $\mathrm{CB}$; content of $\mathrm{Mg}$ was by $25 \%$ higher $(24 \mathrm{~h})$ than in the control but slightly lower than in CB; content of $\mathrm{P}$ was by $14 \%$ higher ( $24 \mathrm{~h}$ ) than in the control but slightly lower than in $\mathrm{CB}$ and the content of $\mathrm{S}$ was by $16 \%$ higher (24 h) than in the control but slightly lower than in CB.

The multielemental composition of the radish cultivated from seeds treated with Spirulina homogenate before sowing is presented in Table 5. Generally, in the case of microelements ( $\mathrm{B}, \mathrm{Cu}, \mathrm{Fe}, \mathrm{Mn}, \mathrm{Ni}$ and $\mathrm{Zn}$ ) the best results were obtained for the highest dose $-700 \mu \mathrm{L}$ (with the exception for $\mathrm{B}-100 \mu \mathrm{L}$ and $\mathrm{Ni}-500 \mu \mathrm{L}$ ). The content of $\mathrm{B}$ was 2.6 times higher for the dose $700 \mu \mathrm{L}$ and 6 times higher for $100 \mu \mathrm{L}$ than in the control group (water) and by $12 \%$ higher and 2.8 times, respectively when compared with the commercial biostimulant (CB); the content of $\mathrm{Cu}$ was by $49 \%$ higher for the dose $700 \mu \mathrm{L}$ than in the control and by $18 \%$ than in $\mathrm{CB}$; the content of $\mathrm{Fe}$ was by $30 \%$ higher for the dose $700 \mu \mathrm{L}$ than in the control and by $11 \%$ than in $\mathrm{CB}$; the content of Mn was by $64 \%$ higher for the dose $700 \mu \mathrm{L}$ than in the control and by $24 \%$ than in $\mathrm{CB}$; the content of Ni was by $61 \%$ higher for the dose $700 \mu \mathrm{L}$ and about 2 times higher for $500 \mu \mathrm{L}$ than in the control but the content was lower when compared with $\mathrm{CB}$ and the content of $\mathrm{Zn}$ was by $47 \%$ higher for the dose $700 \mu \mathrm{L}$ than in the control and by $20 \%$ than in $\mathrm{CB}$. In the case of the macroelements content, the level of $\mathrm{Ca}$ and $\mathrm{Mg}$ was the highest in the group $700 \mu \mathrm{L}$, whereas $\mathrm{K}$,
$\mathrm{P}$ and $\mathrm{S}$ in the group- $100 \mu \mathrm{L}$. The differences in their content in radish were as follows: Ca was by $53 \%$ higher for the dose $700 \mu \mathrm{L}$ than in the control and by $15 \%$ than in $\mathrm{CB} ; \mathrm{Mg}$ was by $52 \%$ higher for the dose $700 \mu \mathrm{L}$ than in the control and by $21 \%$ than in CB; K was by $28 \%$ higher for the dose $100 \mu \mathrm{L}$ than in the control and by $22 \%$ than in CB; P was by $28 \%$ higher for the dose $100 \mu \mathrm{L}$ than in the control and by $11 \%$ than in CB; S was by $29 \%$ higher for the dose $100 \mu \mathrm{L}$ than in the control and by $10 \%$ than in CB. Summarizing the results concerning the elemental composition of radish cultivated from the seeds treated with Spirulina homogenate, a dose $700 \mu \mathrm{L}$ per $1.5 \mathrm{~g}$ of seeds can be recommended for further research - pot experiments in a greenhouse and then field trials.

To sum up, the highest content of micro- and macroelements in the radish was obtained for the following groupsseed soaking in $15 \%$ Spirulina filtrate for $24 \mathrm{~h}$, seed coating at a dose of $700 \mu \mathrm{L}$ of Spirulina homogenate per $1.5 \mathrm{~g}$ of seeds and foliar spray with $20 \%$ Spirulina filtrate. Among these treatments, the smallest effect on the elemental content of radish had seeds soaking. Taking into account the production process and then practical application in greenhouse or field experiments, foliar method seems to be the most efficient.

\section{Discussion}

In the present paper we examined the biostimulant properties of Spirulina products applied in the radish cultivation. Radish was used as a model plant since it reaches quite quickly the mature state (13 days).

\section{The effect of Spirulina products on the radish length}

All concentrations of Spirulina filtrates influenced statistically the length of the above-ground biomass. These results are in agreement with the literature data (Table 1). Michalak et al. (2016) studied the impact of $10 \%$ Spirulina extract, obtained by supercritical fluid extraction, applied in three different doses $1.0,1.5$, and $1.8 \mathrm{~L} \mathrm{ha}^{-1}$ on winter wheat (variety Akteur). Authors found that this biostimulant did not influence significantly the plant length. Opposite results were published by Aghofack-Nguemezi et al. (2015) who studied the effect of Spirulina platensis aqueous extract on the growth parameters and development of tomato plants. Particularly, the foliar spraying of aqueous extracts $(3 \%)$ increased the plant length by $19 \%$ and the diameter by $33 \%$.

For seeds soaking in $15 \%$ Spirulina filtrate, all examined treatments (different soaking period) had a beneficial influence on radish growth in comparison with the control group. This confirms results obtained by other authors. Aung (2011) prepared different concentrations of Spirulina 


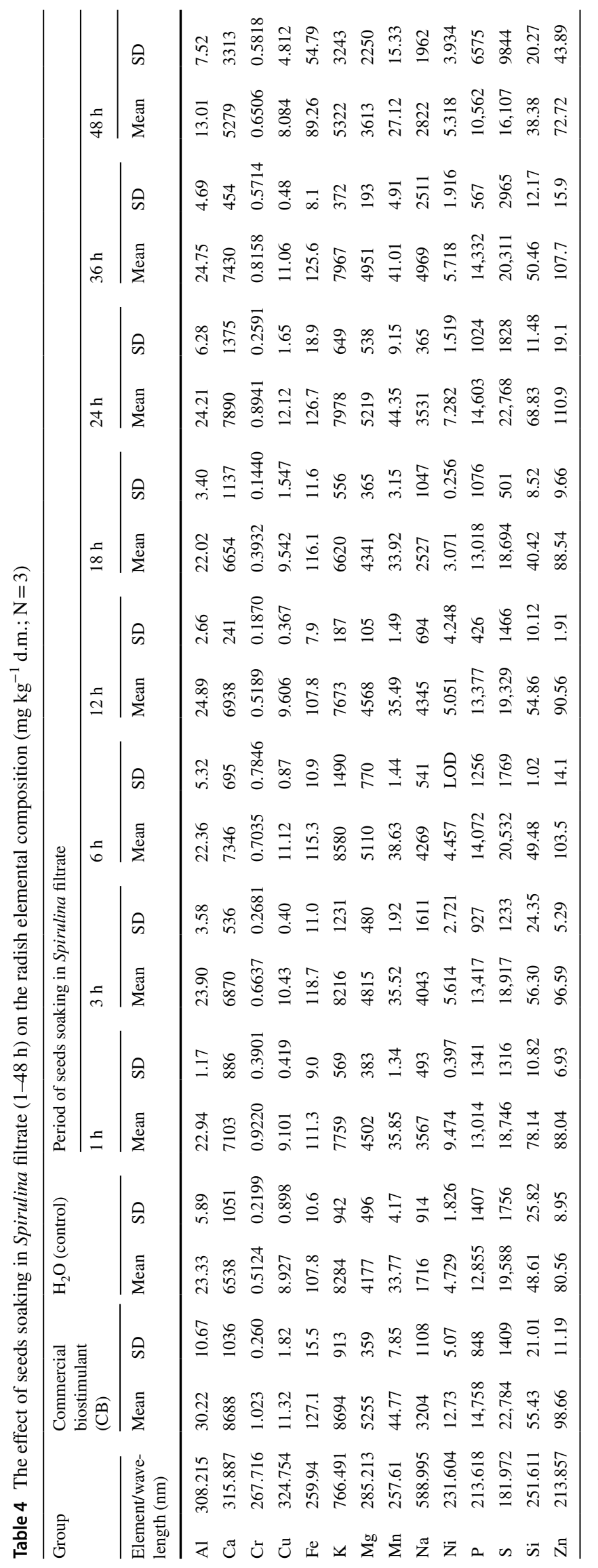


Table 5 The effect of seeds coating in Spirulina homogenate (100-700 $\mu \mathrm{L}$ per $1.5 \mathrm{~g}$ of seeds) on the radish elemental composition (mg kg ${ }^{-1}$ d.m.; $\mathrm{N}=3$ )

\begin{tabular}{|c|c|c|c|c|c|c|c|c|c|c|c|c|c|}
\hline \multirow{2}{*}{\multicolumn{2}{|c|}{ Group }} & \multirow{2}{*}{\multicolumn{2}{|c|}{$\begin{array}{l}\text { Commercial } \\
\text { biostimulant (CB) }\end{array}$}} & \multirow{2}{*}{\multicolumn{2}{|c|}{$\mathrm{H}_{2} \mathrm{O}$ (control) }} & \multicolumn{8}{|c|}{ Dose of Spirulina homogenate for seeds coating } \\
\hline & & & & & & \multicolumn{2}{|l|}{$100 \mu \mathrm{L}$} & \multicolumn{2}{|l|}{$300 \mu \mathrm{L}$} & \multicolumn{2}{|l|}{$500 \mu \mathrm{L}$} & \multicolumn{2}{|l|}{$700 \mu \mathrm{L}$} \\
\hline \multicolumn{2}{|c|}{$\begin{array}{l}\text { Element/wave- } \\
\text { length (nm) }\end{array}$} & Mean & SD & Mean & SD & Mean & SD & Mean & SD & Mean & SD & Mean & SD \\
\hline $\mathrm{Al}$ & 308.215 & 30.22 & 10.67 & 23.33 & 5.89 & 221.2 & 113.9 & 39.66 & 18.56 & 27.73 & 2.47 & 35.89 & 3.53 \\
\hline $\mathrm{Ca}$ & 315.887 & 8688 & 1036 & 6538 & 1051 & 9319 & 933 & 9026 & 751 & 9806 & 726 & 9994 & 703 \\
\hline $\mathrm{Cr}$ & 267.716 & 1.023 & 0.260 & 0.5124 & 0.2200 & 1.067 & 0.679 & 0.9426 & 0.2964 & 0.9240 & 0.5532 & 0.9749 & 0.9225 \\
\hline $\mathrm{Cu}$ & 324.754 & 11.32 & 1.82 & 8.927 & 0.898 & 12.15 & 0.64 & 12.36 & 0.91 & 11.83 & 1.09 & 13.31 & 1.15 \\
\hline $\mathrm{Fe}$ & 259.94 & 127.1 & 15.5 & 107.8 & 10.6 & 133.0 & 8.9 & 131.5 & 9.5 & 134.9 & 11.5 & 140.7 & 3.2 \\
\hline $\mathrm{K}$ & 766.491 & 8694 & 913 & 8284 & 942 & 10,595 & 1932 & 10,072 & 678 & 10,254 & 1060 & 9619 & 2764 \\
\hline $\mathrm{Mg}$ & 285.213 & 5255 & 359 & 4177 & 496 & 5661 & 602 & 5574 & 183 & 6003 & 248 & 6366 & 385 \\
\hline Mn & 257.61 & 44.77 & 7.85 & 33.77 & 4.17 & 42.86 & 4.10 & 50.90 & 9.93 & 52.50 & 2.95 & 55.54 & 6.66 \\
\hline $\mathrm{Na}$ & 588.995 & 3204 & 1108 & 1716 & 914 & 4096 & 1147 & 4756 & 1523 & 3186 & 436 & 2587 & 334 \\
\hline $\mathrm{Ni}$ & 231.604 & 12.73 & 5.07 & 4.730 & 1.826 & 4.332 & LOD & 4.267 & 3.272 & 10.24 & LOD & 7.623 & 4.489 \\
\hline $\mathrm{P}$ & 213.618 & 14,758 & 848 & 12,855 & 1407 & 16,442 & 1634 & 15,763 & 451 & 15,428 & 723 & 16,367 & 1281 \\
\hline S & 181.972 & 22,785 & 1409 & 19,588 & 1756 & 25,183 & 1932 & 22,718 & 2549 & 24,654 & 1337 & 24,866 & 1879 \\
\hline $\mathrm{Si}$ & 251.611 & 55.43 & 21.01 & 48.61 & 25.82 & 72.57 & 16.16 & 79.15 & 18.54 & 62.64 & 5.05 & 64.94 & 3.21 \\
\hline $\mathrm{Zn}$ & 213.857 & 98.66 & 11.19 & 80.56 & 8.95 & 117.8 & 9.9 & 110.1 & 8.6 & 118.4 & 15.6 & 118.7 & 10.5 \\
\hline
\end{tabular}

suspensions $\left(1,3,5,7,9 \mathrm{~g} \mathrm{~L}^{-1}\right)$ and soaked seeds of Vigna radiata for $6 \mathrm{~h}$. The untreated seeds (a control group) were pre-soaked in a purified water. In the 10th week of cultivation, plants in all experimental groups were higher than in the control, while the highest concentration produced the maximum plant length ( $12 \%$ longer). It can be seen that with the increasing doses of suspensions, the plant length also increased. Wuang et al. (2016) investigated the effect of Spirulina inoculation on seed germination. Trials were conducted on three types of vegetables-Chinese Cabbage (B. rapa ssp. chinensis), Kai Lan (Brassica oleracea alboglabra) and White Crown (B. rapa ssp. chinensis, F1 hybrid). The treatments were made at various concentrations of microalga $\left(2,4,6,8\right.$ and $\left.10 \mathrm{~g} \mathrm{~L}^{-1}\right)$ in tap water and control (tap water only). The seeds were soaked in the solutions overnight before germination on a tissue towel. For Chinese Cabbage, the only improvement in shoot length was observed for $4 \mathrm{~g} \mathrm{~L}^{-1}$ (14\% longer). In the case of Kai Lan, almost all dilutions showed biostimulating properties (except $8 \mathrm{~g} \mathrm{~L}^{-1}$ ) and the highest plants were after application of $2 \mathrm{~g} \mathrm{~L}^{-1}$ (18\% longer). There were no significant improvements in the shoot length of White Crown.

Spirulina homogenate, similarly like Spirulina filtrate used as a foliar spray or for seed soaking stimulated the above-ground radish length. The results obtained by Dmytryk et al. (2014) also proved that microalga Spirulina could be used for seed coating. In their work the impact of algal formulations containing 10 and $25 \%$ of supercritical $\mathrm{CO}_{2}$ extracts from Spirulina sp. on Triticum aestivum ssp. vulgare variety Zyta was investigated. Different doses of extracts were used i.e.: for $10 \%-10,20,100 \mu \mathrm{L}$ per $1 \mathrm{~g}$ of seeds and for $25 \%-8,14,20 \mu \mathrm{L}$ per $1 \mathrm{~g}$ of seeds. The lower concentration of the product (10\%) in a dose of $20 \mu \mathrm{L}$ proved to be the most stimulating the plant growth (12\% higher when compared with water), while in higher concentrations (25\%) -8 and $14 \mu \mathrm{L}$ were slightly better than the control (6\% higher). In the work of Hegazi et al. (2010), the effect of the treatment of common bean (Phaseolus vulgaris L.) seeds with dry microalga under different nitrogen levels on the plant length was investigated. In the case of plant length, in the first year of research, addition of Spirulina was as effective as the application of $100 \% \mathrm{~N}$ and in the second year caused the increase in plant length by $12 \%$ for the combination with $75 \% \mathrm{~N}$.

It is worth mentioning, that the seed treatment before sowing (including seed soaking and seed coating) can play an important role in the increasing of the crops productivity due to the maintenance of the seeds quality and the improvement of their germination (Singh et al. 2015). The positive effect of these treatments on plant growth can result also from the absorption of nutrients, protectants, growth regulators by seeds from the appropriate solutions for extended periods (Scott 1989, 1998). In the present study, seeds were immersed in Spirulina products, which can serve as a rich source of novel and biochemically active natural compounds. Cyanobacteria are known to contain a wide variety of compounds, which include $40 \%$ of lipopeptides (with cytotoxic $(41 \%)$, antitumor (13\%), antiviral (4\%), antibiotics activity (12\%) and the remaining $18 \%$ activities include anti-malarial, antimycotics, multidrug resistance reversers, antifeedant, 
herbicides and immunosuppressive agents), 5.6\% of amino acids, $4.2 \%$ of fatty acids, $4.2 \%$ of macrolides and $9 \%$ of amides (Singh et al. 2008). Spirulina platensis used in the present study is rich in free and bound amino acids, including alanine, glycine, valine, leucine, isoleucine, asparagine, aspartic acid, glutamine, glutamic acid, lysine, arginine, histidine, phenylalanine, tyrosine, tryptophan, serine, threonine, methionine, cysteine and proline (Nawrocka et al., 2017). Osman et al. (2016) showed that Spirulina suspension can also induce the biosynthesis of proteins and amino acids in roots and shoots, which can act as a protector from harmful effect of herbicides. In the work of Nawrocka et al. (2017) it was also shown that Spirulina platensis contains also pigment-phycocyanin $\left(266 \pm 23 \mathrm{mg} 100 \mathrm{~g}^{-1}\right.$ d.m. $)$, polyphenols, determined with Folin-Ciocalteu reagent $(176 \pm 5 \mathrm{mg}$ $100 \mathrm{~g}^{-1}$ expressed as equivalents of gallic acid), vitamins

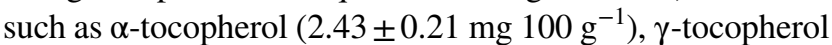

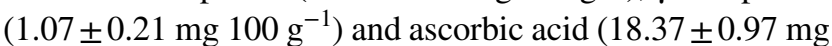
$100 \mathrm{~g}^{-1}$ ). All these compounds can be responsible for the biostimulant properties of Spirulina formulations. Mógor et al. (2018) showed also that the enzymatic hydrolysates of Spirulina platensis had a cytokinin-like effect which effectively promoted lettuce growth (Table 1).

\section{The effect of Spirulina products on the fresh mass of radish}

In the present paper it was shown that all Spirulina products influenced positively the fresh mass of radish what confirms literature data for example (Hegazi et al. 2010; Tuhy et al. 2015; Wuang et al. 2016; Mógor et al. 2018) (Table 1). Aghofack-Nguemezi et al. (2015) presented that Spirulina platensis can affect the fresh biomass of aerial parts of tomato plants by $48 \%$ and the fruit biomass by $43 \%$ when compared with the control group (no treatment). Michalak et al. (2016) investigated the impact of microalgal extracts on the yield parameters of grain and mass of 1000 grains of winter wheat (variety Akteur). The grain yield was comparable in all tested groups (all doses of Spirulina ranged from 1 to $1.8 \mathrm{~L} \mathrm{ha}^{-1}$, control and commercial biostimulants). The statistically significant differences were noted for the mass of 1000 grains. The highest mass was obtained for Spirulina $-1.8 \mathrm{~L} \mathrm{ha}^{-1}$, Spirulina-1.0 $\mathrm{L} \mathrm{ha}^{-1}$, in comparison with the control group by approximately $16 \%$. The lowest mass was observed for $1.5 \mathrm{~L} \mathrm{ha}^{-1}$ Spirulina extract (higher than in control approx. by $13 \%$ ). In the work of Aung (2011), the effect of Spirulina biofertilizer suspension on the growth and yield of Vigna radiata was examined. Among all the concentrations (ranged from 1 to $9 \mathrm{~g} \mathrm{~L}^{-1}$ of Spirulina suspension), $7 \mathrm{~g} \mathrm{~L}^{-1}$ produced the maximum seed yield $\left(238 \mathrm{~g} \mathrm{~m}^{-2}\right)$ of Vigna radiata (L.). The second, highest yield was produced from $9 \mathrm{~g} \mathrm{~L}^{-1}$ treatment $\left(229 \mathrm{~g} \mathrm{~m}^{-2}\right)$. The yield of the control was found to be the lowest $\left(172 \mathrm{~g} \mathrm{~m}^{-2}\right)$. In the work of Mógor et al. (2018), the increase of the fresh biomass of cucumber was attributed to the cytokinin-like activity of Spirulina hydrolysates.

In the literature, the positive effect of algal homogenates on the growth of plants is known and confirms our results (Table 1). In the work of Dmytryk et al. (2014), the wet biomass of winter wheat was about $16 \%$ and $13 \%$ heavier after application of $20 \mu \mathrm{L}$ of $10 \%$ and $8 \mu \mathrm{L}$ of $25 \%$ formulation than for control group (water). Hegazi et al. (2010) observed that the microalga increased the fresh mass of common bean-for example in a combination with $75 \% \mathrm{~N}$ and seed coating with Spirulina, plants were heavier by $26 \%$ in the first year and by $22.5 \%$ in the second year in comparison with the control with higher dose of $\mathrm{N}(100 \%)$. This solution can reduce the amount of used chemical fertilizers.

The positive effect of Spirulina products on the length and fresh mass of radish is also beneficial from the medical point of view. It is worth emphasizing that both leaves and roots of radish have been used in various parts of the world as antiviral (e.g., against influenza virus), antimicrobial, antioxidant agents and also to treat cancer (Pérez Gutiérrez and Perez 2004). Radish leaves were also found to reduce intestinal glucose absorption (Banihani 2017).

\section{The effect of Spirulina products on the chlorophyll content in radish}

As it was shown in the present study, Spirulina products can also increase the chlorophyll content in the leaves of germinated radish, especially after the application of 5\% filtrate, soaking of seeds for $48 \mathrm{~h}$ and coating of seeds in $100 \mu \mathrm{L}$ of homogenate. Dmytryk et al. (2014) stated that chlorophyll content in Cucumis sativus was affected by neither supercritical extract from Spirulina nor reference products when compared with the control groups. In the work of Hegazi et al. (2010), the effect of seed coating with Spirulina and the simultaneous application of nitrogen fertilizer on the chlorophyll content in leaves of common bean was presented. In the first year, the use of alga and appropriate doses (50 and 75\%) of $\mathrm{N}$ resulted in a higher content of a green pigment (13 and $16.5 \%$ more, respectively) in comparison with $100 \%$ of $\mathrm{N}$; whereas in the second year results were comparable. Spirulina applied to the soil can increase not only the chlorophyll content in the leaves, but also the content of proteins and amino acids (Bhowmik et al. 2010; Osman et al. 2016; Mala et al. 2017), vitamin A (Mala et al. 2017) and antioxidant activity of the cultivated biomass (Mala et al. 2017). Higher chlorophyll content in the leaves can also result from the higher leaf area due to the action of Spirulina hydrolysate (Mógor et al. 2018), or dry algal biomass used for seeds coating (Hegazi et al. 2010). 


\section{Multielemental composition of the above-ground biomass of radish}

Micro- and macroelements, as well as other nutrients present in Spirulina products play a major role in plant metabolism (e.g., physiological activities like cellular organization, protein and nucleic acid metabolisms) (Anitha et al. 2016). They influence not only growth and development of the cultivated plants, but also their chemical composition. Therefore, they can be useful and beneficial for human nutrition and health. In this work, Spirulina platensis products, rich in micro- and macroelements biofortified the above-ground biomass of radish with mineral elements. Their content was higher in the radish from experimental groups when compared with the control group. The presence of bioactive compounds (e.g., amino acids, carbohydrates, peptides) in biostimulants of plant growth such as Spirulina filtrate/ homogenate can increase the content of minerals in the plant due to increased sink strength that influences the movement of substrates, including minerals, within the plant (Calvo et al. 2014). Biostimulants of plant growth improve also the mineral uptake by the well-developed root system (improved lateral root formation and increased total volume of the root system) and leaves (increased number of leaves per plant and their area) (Khan et al. 2009).

In the literature it was shown that the application of Spirulina products can increase the content of micro- and macroelements in the crops, fruits, vegetables. For example, Tuhy et al. (2015) recorded enrichment of maize with $\mathrm{Zn}$, $\mathrm{Mn}$ and $\mathrm{Cu}$ derived from a solid Spirulina biomass applied as a micronutrient fertilizer. Anitha et al. (2016) examined the effect of different concentrations of Spirulina suspension in water $\left(5,10,15\right.$ and $\left.20 \mathrm{~g} \mathrm{~L}^{-1}\right)$ on the content of zinc in the biomass of Amaranthus gangeticus, Phaseolus aureus and tomato plants. The results showed that Spirulina filtrate applied foliarly can help to accumulate essential substances (e.g., zinc) which are needed for plant growth. In the work of the same author, it was shown that soaking of seeds of Amaranthus gangeticus, Phaseolus aureus and tomato plants for $1,2,3,4,5,25 \mathrm{~h}$ in the suspension of $5 \mathrm{~g}$ of Spirulina in $100 \mathrm{~mL}$ of water generally resulted in the enrichment of plants in zinc. For Amaranthus gangeticus the best soaking time was $4 \mathrm{~h}\left(54.5 \mathrm{mg} \mathrm{kg}^{-1}\right)$, for Phaseolus aureus-3 h $\left(50.8 \mathrm{mg} \mathrm{kg}^{-1}\right)$ and for tomato plants-2 $\mathrm{h}\left(5.28 \mathrm{mg} \mathrm{kg}^{-1}\right)$.

The biomass of radish biofortified with microelements can be used to prevent from so called "hidden hunger" which is referred to micronutrient deficiencies (Kennedy et al. 2003; Burchi et al. 2011). This is a global challenge to health, especially of vulnerable population like women and children all over the world. One of the strategies for addressing micronutrient malnutrition is fortification (including biofortification). A crucial is also dietary diversification and supplementation (Kennedy et al. 2003).
Summarizing, in the present study, we examined the effect of natural products (filtrates and homogenates) obtained from microalga Spirulina platensis in the cultivation of radish. Most of tested biostimulants increased the length of plants in comparison to control and commercial product. The longest aerial parts of radish were in the group treated with $15 \%$ of spray, soaked for $6 \mathrm{~h}$ in $15 \%$ of filtrate, and coated with $300 \mu \mathrm{L}$ of homogenate per $1.5 \mathrm{~g}$ of seeds. In the case of wet mass, $15 \%$ of filtrate, $48 \mathrm{~h}$ of soaking and 300 and $100 \mu \mathrm{L}$ of homogenate for coating proved to be the mostly stimulating. The highest concentration of chlorophyll was in groups sprayed with $5 \%$ of filtrate, soaked for $48 \mathrm{~h}$ and coated with $100 \mu \mathrm{L}$ of product. It was found that taking into account the content of micro- and macroelements in the biomass of cultivated radish it was the highest in the following groups-seeds soaking for $24 \mathrm{~h}$, seeds coating at a dose of $700 \mu \mathrm{L}$ of homogenate per $1.5 \mathrm{~g}$ of seeds and foliar spray of Spirulina extract at a concentration of $20 \%$. These applications resulted in the production of biofortified edible vegetables that can be beneficial to human health. For further research—greenhouse experiments and then field trials, Spirulina extract applied foliarly is highly recommended.

Acknowledgements The work was co-financed by statutory activity subsidy in 2018 from the Polish Ministry of Science and Higher Education for the Faculty of Chemistry of Wrocław University of Science and Technology (Department of Advanced Material Technologies)-No. 0401/0157/18.

\section{Compliance with ethical standards}

Conflict of interest The authors declare that they have no conflict of interest.

Research involving human participants and/or animals This article does not contain any studies with human participants or animals performed by any of the authors.

Open Access This article is distributed under the terms of the Creative Commons Attribution 4.0 International License (http://creativeco mmons.org/licenses/by/4.0/), which permits unrestricted use, distribution, and reproduction in any medium, provided you give appropriate credit to the original author(s) and the source, provide a link to the Creative Commons license, and indicate if changes were made.

\section{References}

Aghfack-Nguemezi J, Passannet A, Schinzoumka et Valère T (2015) Effets des extraits ou de la poudre de Spirulina platensis et Jatropha curcas sur la croissance et le développement de la tomate. J Appl Biosci 90:8413-8420

Anitha L, Sai Bramari G, Kalpana P (2016) Effect of supplementation of Spirulina platensis to enhance the zinc status in plants of Amaranthus gangeticus, Phaseolus aureus and tomato. Adv Biosci Biotechnol 7:289-299 
Aung KLN (2011) Effect of Spirulina biofertilizer suspension on growth and yield of Vigna radiata (L.) Wilczek. Univ Res J 4(1):351-363

Banihani SA (2017) Radish (Raphanus sativus) and diabetes. Nutrition 9:1014. https://doi.org/10.3390/nu9091014

Bhowmik D, Dubey J, Mehra S (2010) Evaluating potential of Spirulina as innoculant for pulses. Acad J Plant Sci 3(4):161-164

Burchi F, Fanzo J, Frison E (2011) The role of food and nutrition system approaches in tackling hidden hunger. Int J Environ Res Public Health 8:358-373

Calvo P, Nelson L, Kloepper JW (2014) Agricultural uses of plant biostimulants. Plant Soil 383:3-41

Crouch IJ, van Staden J (1993) Evidence for the presence of plant growth regulators in commercial seaweed products. Plant Growth Regul 13:21-29

Dmytryk A, Rój E, Wilk R, Chojnacka K (2014) Innovative bioformulations for seed treatment. Preliminary assessment of functional properties in the initial plant growth phase. Przem Chem 93(6):959-963

du Jardin P (2015) Plant biostimulants: Definition, concept, main categories and regulation. Sci Hortic 196:3-14

Hegazi AZ, Mostafa SSM, Ahmed HMI (2010) Influence of different cyanobacterial application methods on growth and seed production of common bean under various levels of mineral nitrogen fertilization. Nat Sci 8(11):183-194

Kennedy G, Nantel G, Shetty PS (2003) The scourge of "hidden hunger": Global dimensions of micronutrient deficiencies. Food Nutr Agric 32:8-16

Khan W, Rayirath UP, Subramanian S, Jithesh MN, Rayorath P, Hodges DM, Critchley AT, Craigie JS, Norrie J, Prithiviraj B (2009) Seaweed extracts as biostimulants of plant growth and development. J Plant Growth Regul 28:386-399

Mala R, Ruby Celsia AS, Mahalakshmi R, Rajeswari S (2017) Agronomic biofortification of Amaranthus dubius with macro nutrients and vitamin A. In: IOP Conference Series: Materials Science and Engineering. https://doi.org/10.1088/1757-899X/225/1/012214

Michalak I, Chojnacka K, Dmytryk A, Wilk R, Gramza M, Rój E (2016) Evaluation of supercritical extracts of algae as biostimulants of plant growth in field trials. Front Plant Sci 7:1591. https ://doi.org/10.3389/fpls.2016.01591

Michalak I, Dmytryk A, Schroeder G, Chojnacka K (2017) The application of homogenate and filtrate from Baltic seaweeds in seedlings growth tests. Appl Sci 7(3):230. https://doi.org/10.3390/ app7030230

Mishra U, Pabbi S (2004) Cyanobacteria: a potential biofertilizer for rice. Reson 6:6-10
Mógor ÁF, Ördög V, Pace Pereira Lima G, Molnár Z, Mógor G (2018) Biostimulant properties of cyanobacterial hydrolysate related to polyamines. J Appl Phycol 30:453-460

Nawrocka D, Kornicka K, Śmieszek A, Marycz K (2017) Spirulina platensis improves mitochondrial function impaired by elevated oxidative stress in Adipose-Derived Mesenchymal Stromal Cells (ASCs) and Intestinal Epithelial Cells (IECs), and enhances insulin sensitivity in Equine Metabolic Syndrome (EMS) horses. Mar Drugs 15:237. https://doi.org/10.3390/md15080237

Osman MEH, Abo-Shady AM, El-Nagar MMF (2016) Cyanobacterial Arthrospira (Spirulina platensis) as safener against harmful effects of fusilade herbicide on faba bean plant. Rend Fis Acc Lincei 27:455-462

Pérez Gutiérrez RMP, Perez RL (2004) Raphanus sativus (Radish): their chemistry and biology. Sci World J 4:811-837

Scott JM (1989) Seed coatings and treatments and their effects on plant establishment. Adv Agron 42:43-83

Scott JM (1998) Delivering fertilizers through seed coatings. J Crop Prod 1:197-220

Singh S, Kate BN, Banerjee UC (2008) Bioactive compounds from cyanobacteria and microalgae: an overview. Crit Rev Biotechnol 25(3):73-95

Singh RP, Prasad PVV, Reddy KR (2015) Climate change: implications for stakeholders in genetic resources and seed sector. Adv Agron 129:117-180

Singh JS, Kumar A, Rai AN, Singh DP (2016) Cyanobacteria: a precious bio-resource in agriculture, ecosystem, and environmental sustainability. Front Microbiol 7:529. https://doi.org/10.3389/ fmicb.2016.00529

Sornchai P, Saithong N, Srichompoo Y, Unartngam A, Iamtham S (2014) Effect of Spirulina maxima aqueous extract on seed germination and seedling growth of mung bean, Vigna radiata and rice, Oryza sativa var. Japonica. J Int Soc South Asian Agric Sci 20(2):77-84

Tuhy Ł, Samoraj M, Witkowska Z, Chojnacka K (2015) Biofortification of maize with micronutrients by Spirulina. Open Chem 13:1119-1126

Wuang SC, Khin MC, Chua PQD, Luo YD (2016) Use of Spirulina biomass produced from treatment of aquaculture wastewater as agricultural fertilizers. Algal Res 15:59-64

Publisher's Note Springer Nature remains neutral with regard to jurisdictional claims in published maps and institutional affiliations. 